Biosens. Bioelectron. 2014, 55, 301-306, doi.org/10.1016/j.bios.2013.12.030

\title{
Electrochemical immunosensor for detection of antibodies against influenza A virus H5N1 in hen serum
}

Urszula Jarocka $^{\text {a }}$, Róża Sawicka ${ }^{\mathrm{b}}$, Anna Góra-Sochacka ${ }^{\mathrm{b}}$, Agnieszka Sirko ${ }^{\mathrm{b}}$, Włodzimierz Zagórski-Ostoja ${ }^{\mathrm{b}}$, Jerzy Radecki ${ }^{\mathrm{a}}$, Hanna Radecka ${ }^{*}$,

${ }^{a}$ Institute of Animal Reproduction and Food Research of Polish Academy of Sciences, Tuwima 10, 10-748 Olsztyn, Poland

${ }^{\mathrm{b}}$ Institute of Biochemistry and Biophysics, Polish Academy of Sciences, Pawińskiego 5A, 02-106 Warsaw, Poland

* Corresponding autor tel.: +48 89523 4636; fax: +48 89524 0124; e-mail address:

h.radecka@pan.olsztyn.pl

\begin{abstract}
This paper describes the development of an immunosensor for detection of anti-hemagglutinin antibodies. Its preparation consists of successive modification steps of glassy carbon electrodes: (i) creation of $\mathrm{COOH}$ groups, (ii) covalent immobilization of protein A with EDC/NHS coupling reaction, (iii) covering with anti-His IgG monoclonal antibody, (iv) immobilization of the recombinant His-tagged hemagglutinin ( $\mathrm{His}_{6}-\mathrm{H} 5 \mathrm{HA}$ ), (v) filling free space with BSA. The interactions between two variants of recombinant HA (short and long) from highly pathogenic avian influenza virus $\mathrm{H} 5 \mathrm{~N} 1$ and the anti-H5 HA monoclonal antibody (Mab 6-9-1) have been explored with electrochemical impedance spectroscopy (EIS). The impedimetric immunosensor displayed a very good detection limit (LOD) of $2.1 \mathrm{pg} / \mathrm{mL}$, the quantification limit (LOQ) of $6.3 \mathrm{pg} / \mathrm{mL}$ and a dynamic range from $4 \mathrm{pg} / \mathrm{mL}$ to $20 \mathrm{pg} / \mathrm{mL}$. In addition, this analytical device was applied for detection of antibodies against $\mathrm{His}_{6}-\mathrm{H} 5 \mathrm{HA}$ in serum of vaccinated hen using serial 10-fold dilutions of serum. The immunosensor proposed was able to detect antibody in hen serum diluted up to 7 x $10^{7}$-fold. The sensitivity of immunosensor was about four orders of magnitude much better than ELISA.
\end{abstract}


Keywords: Glassy carbon electrodes, Detection of antibody, Avian influenza virus, Immunosensor, Electrochemical impedance spectroscopy

\section{Introduction}

Avian influenza (AI) is a highly contagious disease caused by Orthomyxoviridae family viruses (Boon et al., 2001; Li et al., 2011). Highly pathogenic avian influenza viruses can be easily transmitted between poultry production facilities, leading to severe disease outbreaks or even pandemics. It is difficult to control the spread, so all chickens in facilities are usually slaughtered (Peng et al., 2007). All causes enormous economic losses in the poultry industry and seriously threatens human health (Dhumpa et al., 2011; Guan et al., 2002; Shortridge et al., 1998). To prevent and control AI in poultry, vaccination has been employed as a key strategy in many countries since the 1990s (Nilsson et al., 2010; Peng et al., 2007). According to European regulation (Council Directive 2005/94/EC) programmes of industrial birds vaccination against AI, the DIVA (Differentiating Infected from Vaccinated Animals) strategy should be applied in order to reduce the risk of a "silent spread" of the virus due to incomplete protection at a flock level.

The conventional methods most frequently used for detection of antibodies against influenza A virus are enzyme-linked immunosorbent assays (ELISA) (Chen et al., 2011; Ciacci-Zanella et al., 2010; Hoque et al., 2012; Lebarbenchon et al., 2012; Moreno et al., 2013), hemagglutination inhibition (HI) (Allwinn et al., 2010; Schultsz et al., 2009; Peng et al., 2007) and Western blot assay (WB) (Uyeki et al., 2012). Nevertheless, they are often laborious and time-consuming or need expensive instruments. Therefore, there is still significant need to explore some simple, sensitive, and low cost diagnostic methods for detection of antibodies against influenza A virus.

Immunosensors incorporating specific antigen are a promising alternative systems for the detection of antibodies. Many different type of immunosensors have been successfully developed such as piezoelectric (Wang et al., 2012; Shen et al., 2005), based on surface plasmon resonance (SPR) (Puttharugsa et al., 2013; Souto et al., 2013; Gupta et al., 2012; Kim et al., 2009) or based on Love wave mode surface acoustic wave (SAW) (Lee et al., 2009), just to name a few examples. 
The low sample consumption, reasonable cost of instrumentations and good possibility for miniaturization are the main reasons for extensive development of electrochemical immunosensors (Ricci et al., 2012; Anik et al., 2011; Ionescu et al., 2007; Zhou et al., 2003).

Electrochemical impedance spectroscopy (EIS), suitable to measure the electron interfacial transfer resistance is particular useful as the detection method in the sensing systems which display low reversibility, and, because of this, Faradaic current cannot be measure (Lvovich 2012). The impedimetric immunosensors have been already successfully applied for detection of several types of antibodies (Mashazi et al., 2013; Liu et al., 2011; Liu et al., 2010), his-tagged proteins (Wąsowicz et al., 2008, 2010) or antigens (Jarocka et al., 2013; 2011; Caygill et al., 2012).

Here, we present a sensitive and selective immunosensor for the detection of antibodies against hemagglutinin (HA) from highly pathogenic avian influenza virus H5N1. Specific interaction between recombinant His-tagged hemagglutinin ( His $_{6}-\mathrm{H} 5$ HA) and the appropriate monoclonal antibody was observed using electrochemical impedance spectroscopy in the presence of $\left[\mathrm{Fe}(\mathrm{CN})_{6}\right]^{3-/ 4-}$ as an electroactive marker. Finally, the immunosensor was used for detection of specific anti-H5 HA response in hen sera samples and the results were compared with those obtained with ELISA.

To our knowledge, in literature there are no reports on electrochemical immunosensors for detection of anti hemagglutinin antibodies in hen serum.

\section{Experimental}

\subsection{Chemicals, antibodies and antigens}

Protein A, 2-morpholinoethanesulfonic acid (MES), $N$-hydroxysuccinimide (NHS), $N$-(3-dimethylaminopropyl)- $N$ '-ethylcarbodiimide hydrochloride (EDC), ethanolamine, potassium ferro- and ferricyanides, phosphate buffer saline (PBS) components $(\mathrm{NaCl}, \mathrm{KCl}$, $\mathrm{Na}_{2} \mathrm{HPO}_{4}, \mathrm{KH}_{2} \mathrm{PO}$ ), were obtained from Sigma-Aldrich (Poznań, Poland). Alumina 0.3 and $0.05 \mu \mathrm{m}$ was purchased from Buehler (USA). Sulphuric acid and methanol were supplied by POCh (Poland). Bovine serum albumin (BSA) was purchased from Invitrogen Life Technologies (Germany). Anti-hemagglutinin H5 monoclonal antibody (Mab 6-9-1) was from the Institute of Biotechnology and Antibiotics Polish Academy of Sciences (Warsaw, Poland), monoclonal anti-IL-2 antibody was purchased from AbD Serotec (Oxford, UK). Anti-His 
monoclonal antibody was obtained from Novagen (Germany). The sera of chickens were collected and characterized in Institute of Biochemistry and Biophysics Polish Academy of Sciences (Warsaw, Poland). Both recombinant variants of HA antigen (long and short) used in this study are based on the sequence of H5N1 (A/swan/Poland/305-135V08/2006; EpiFlu Database Acc No EPI156789). The long His $_{6}-\mathrm{H} 5$ HA antigen was produced in baculovirus system (Oxford Expression Technologies, UK). It covers region of 17-530 residues with deletion of 6 residues in the proteolytic cleavage site (RRRKKR; 341-346) and contains His-tag at C-terminus. The short $\mathrm{His}_{6}-\mathrm{H} 5 \mathrm{HA}$ antigen was produced in Escherichia coli. It covers region of 17-340 residues (corresponding to the H1 subunit) and contains His-tag at Nterminus. All aqueous solutions were prepared using MilliQ water, resistivity $18.2 \mathrm{M} \Omega \cdot \mathrm{cm}$ (Millipore). Reagents and solvents were of analytical purity and were used without further purification. Experiments were carried out at room temperature unless stated otherwise.

\subsection{ELISA}

Ni-NTA HisSorb (Qiagen) plates were used as suggested by the manufacturer. Briefly, plates were coated overnight at $4^{\circ} \mathrm{C}$ with $300 \mathrm{ng} /$ well of long $\mathrm{His}_{6}$-H5 HA (diluted in PBS buffer [0.2\% BSA in PBS] to final concentration $3 \mathrm{ng} / \mu \mathrm{L}$ or $6 \mathrm{ng} / \mu \mathrm{L}$ depending on the final volume of samples. BSA (300 ng/well; diluted in PBS) was used as a control. Next the strips were washed 4 times (300 $\mu \mathrm{L}$ phosphate buffer saline with Tween 20/well; 10-60 s) and incubated with $100 \mu \mathrm{L} /$ well of either Mab 6-9-1 (protein amounts as indicated; from $34 \mathrm{ng}$ to $5.5 \mu \mathrm{g}$ ) or with $50 \mu \mathrm{Ll} /$ well of chicken serum (two-fold serial dilutions in $0.2 \% \mathrm{BSA}$ in PBS; from $1: 2 \cdot 10^{3}$ to $1: 6.4 \cdot 10^{4}$ ). After $1.5 \mathrm{~h}$ incubation in room temperature (RT), strips were washed as above. Plates were incubated at $37^{\circ} \mathrm{C}$ with the respective secondary antibody, Alkaline Phosphatase (AP)-conjugated anti-mouse IgG or Horse Radish Peroxidase (HRP)conjugated anti-chicken IgG (preincubated with chicken serum) for $45 \min$ or $1 \mathrm{~h}$, respectively. After washing as above, $100 \mu \mathrm{L}$ of the substrate for AP (paranitrophenylphosphate, pNPP) or $50 \mu \mathrm{L}$ for HRP (tetramethylbenzidine, TMB) was added and colour was developed in RT during $45 \mathrm{~min}$ or $30 \mathrm{~min}$, respectively. The reaction with TMB was stopped by adding $50 \mu \mathrm{L}$ of $0.5 \mathrm{M} \mathrm{H}_{2} \mathrm{SO}_{4}$. Absorbance was measured at $405 \mathrm{~nm}$ or 450 $\mathrm{nm}$ for $\mathrm{pNPP}$ or TMB, respectively. 


\subsection{Preparation of immunosensor}

Glassy carbon electrodes (GCE) (3.0 mm diameter) were obtained from BioAnalytical System (BAS), West Lafayette, IN. Electrodes after washing with methanol and water were polished using microcloth polishing pads, first in alumina $0.3 \mu \mathrm{m}$, subsequently in alumina $0.05 \mu \mathrm{m}$ for 5 minutes each. After this step the electrodes were carefully washed and sonicated in milli-Q water for 1 minute.

The pre-treatment procedure to generate carboxylic groups on the electrode surfaces were performed in $0.5 \mathrm{M} \mathrm{H}_{2} \mathrm{SO}_{4}$ using a conventional three-electrode electrochemical cell $(\mathrm{Ag} / \mathrm{AgCl}$ reference electrode and $\mathrm{Pt}$ counter electrode, glassy carbon electrode as working electrode). Measuring conditions were as follows: minimum potential $-0.3 \mathrm{~V}$, maximum potential $1.5 \mathrm{~V}$, scan rate $100 \mathrm{mV} / \mathrm{s}$, number of cycles 20 . After finishing electrochemical pretreatment each electrode was washed with Milli-Q water and placed in water (for several minutes, until the next step) to avoid contaminants from air.

The glassy carbon electrodes functionalized with carboxylic groups were soaked in a mixture of $100 \mathrm{mM}$ EDC and $50 \mathrm{mM}$ NHS in $50 \mathrm{mM}$ MES pH 5.5 for 1 hour. Subsequently, the electrodes were rinsed with MES and PBS pH 7.4 (137 mM NaCl, $10 \mathrm{mM}$ phosphate, $2.7 \mathrm{mM} \mathrm{KCl}$ ), respectively. Then the electrodes were fixed upside down and 10 $\mu \mathrm{L}$ droplets of $10.0 \mu \mathrm{g} / \mathrm{mL}$ protein A in 0.1 M PBS were spotted on each glassy carbon surface. The electrodes were kept for 1 hour, covered by Teflon tape in order to avoid droplets evaporation. The residual NHS esters were blocked by soaking in $1.0 \mathrm{M}$ ethanolamine $\mathrm{pH} 9.0$ for 10 minutes. After that, $10 \mu \mathrm{L}$ droplets of anti-His antibody $(1.0 \mu \mathrm{g} / \mathrm{mL}$ in $0.1 \mathrm{M}$ PBS, $\mathrm{pH}$ 7.4) were deposed and left on the surface of each electrode for 1 hour. Next, $10 \mu \mathrm{L}$ droplets of $1.0 \mu \mathrm{g} / \mathrm{mL}$ long or short $\mathrm{His}_{6}$-HA antigen were placed on glassy carbon surfaces for 1 hour. In order to avoid of unspecific binding, $10 \mu \mathrm{L}$ droplets of BSA solution (in $0.1 \mathrm{M}$ PBS, $\mathrm{pH}$ 7.4) in concentration of $1 \%(\mathrm{~m} / \mathrm{v})$ were deposited on each electrode for 1 hour. Finally, the electrodes were rinsed with 0.1 M PBS, pH 7.4. Fully modified electrodes were stored in a refrigerator $\left(+4^{\circ} \mathrm{C}\right)$ in $0.1 \mathrm{M} \mathrm{PBS}, \mathrm{pH} 7.4$ until used, but not longer than one day. 


\subsection{Cyclic voltammetry (CV) and electrochemical impedance spectroscopy (EIS) measurements}

All electrochemical measurements were performed with Autolab potentiostatgalvanostat (Eco Chemie, Netherlands). Three-electrode configuration was applied: glassy carbon electrode (BAS, USA) as the working electrode, $\mathrm{Ag} / \mathrm{AgCl}$ as the reference electrode and $\mathrm{Pt}$ as the counter electrode. Cyclic voltammetry (CV) and electrochemical impedance (EIS) were performed in the presence of $0.1 \mathrm{M} \mathrm{PBS}(137 \mathrm{mM} \mathrm{NaCl}, 10 \mathrm{mM}$ phosphate, $2,7 \mathrm{mM} \mathrm{KCl}) \mathrm{pH} 7.4$ and $1 \mathrm{mM} \mathrm{K}{ }_{3}\left[\mathrm{Fe}(\mathrm{CN})_{6}\right] / \mathrm{K}_{4}\left[\mathrm{Fe}(\mathrm{CN})_{6}\right](1: 1)$ in order to control each step of electrode modification. All solutions were purged with nitrogen for 10 minutes to provide oxygen free conditions. The $\mathrm{CV}$ potential was cycled from $-0.2 \mathrm{~V}$ to $0.6 \mathrm{~V}$ with scan rate $0.1 \mathrm{~V} / \mathrm{s}$. The EIS procedure was set to measure the electron transfer resistance in frequency range of $0.1 \mathrm{~Hz}$ to $10 \mathrm{kHz}$ at potential of $0.20 \mathrm{~V}$. Obtained spectra were fitted using the Autolab software in order to calculate values of electron transfer resistance $\left(R_{\mathrm{et}}\right)$. The electrode responses were expressed as: $\left(R_{i}-R_{0}\right) / R_{0}$ where: $R_{0}$ means electron transfer resistance of fully modified electrode measured in pure PBS buffer before antibodies detection, $\mathrm{R}_{\mathrm{i}}$ means electron transfer resistance of fully modified electrode measured in PBS containing particular concentration of antibodies or electron transfer resistance of fully modified electrode measured in the presence of sera form vaccinated or unvaccinated hen diluted with buffer.

\section{Results and discussion}

\subsection{Characterization of immunosensor}

The process of the immunosensor formation is shown in Scheme 1. First, $\mathrm{COOH}$ groups are created by oxidation of the electrode surface in $0.5 \mathrm{M} \mathrm{H}_{2} \mathrm{SO}_{4}$ (Pang et al., 1996). Then, glassy carbon electrodes were coated with protein A by covalent linkage to the carboxylic moieties on the electrode surface after activation by mixture of NHS and EDC. The residual NHS esters were blocked by ethanolamine. After that, anti-His antibody was immobilized by a specific interaction of protein A with the Fc region (Boujday et al., 2008, Yuanyuan et al., 2006) of antibody molecules. Through the protein A, the active sites of the antibodies are more easily accessible for the antigen. Next, electrode surfaces were covered 
with either variant of His $_{6}$-H5 HA antigen (long or short) by interaction between his-tagged antigen and anti-His antibody. BSA was used for blocking of unspecific binding sites.

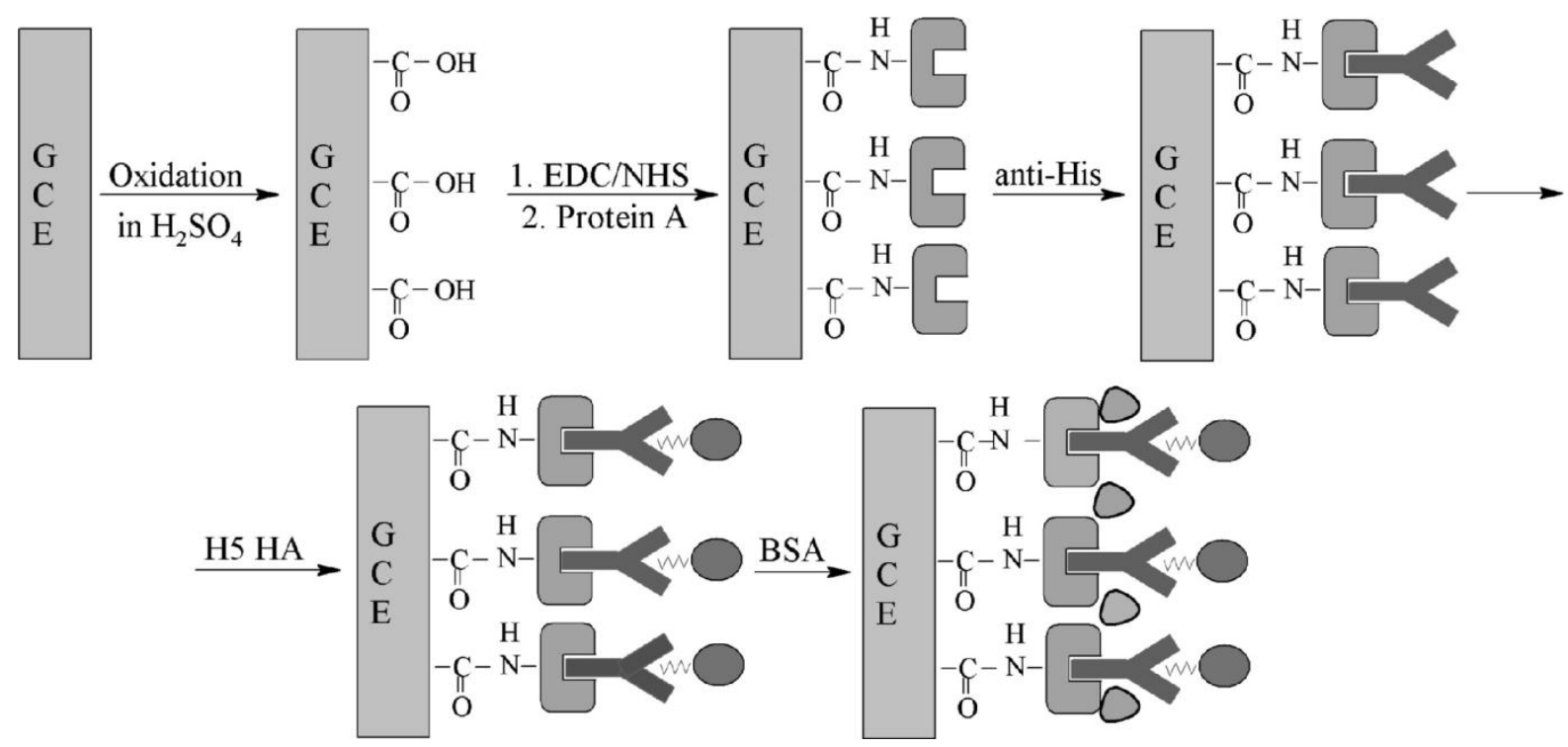

Scheme 1. Steps of immunosensor formation.

Each step of glassy carbon electrodes modification was controlled using CV (Fig. S1) and EIS (Fig. S2) in the presence of $1.0 \mathrm{mM} \mathrm{K}_{3}\left[\mathrm{Fe}(\mathrm{CN})_{6}\right] / \mathrm{K}_{4}\left[\mathrm{Fe}(\mathrm{CN})_{6}\right](1: 1)$ as redox marker in 0.1 M PBS pH 7.4. The bare glassy carbon electrodes have no obstacles affecting electron transfer which results in peak separation $85 \mathrm{mV}$ (Fig. S1, curve a). EIS control of this step produces an almost straight line Nyquist plot (Fig. S2, curve a). These indicate a diffusion controlled electrochemical process. The covalent attachment of protein A on the electrode surfaces reduced the accessibility of the redox marker to electrode surfaces. This increased the peak separation $\Delta \mathrm{E}_{\mathrm{p}}$ to $205 \mathrm{mV}$ (Fig. S1, curve b) and increased the electron transfer resistance $\mathrm{R}_{\mathrm{et}}$ to $8.9 \mathrm{k} \Omega$ (Fig. $\mathrm{S} 2$, curve b). The deposition of antibody led to an increase of the $\mathrm{CV}$ peak separation, $\Delta \mathrm{E}_{\mathrm{p}}$ to $249 \mathrm{mV}$ (Fig. S1, curve c), as well as an increase of the electron transfer resistance, $\mathrm{R}_{\mathrm{et}}$ to $12 \mathrm{k} \Omega$ (Fig. S2, curve c). The immobilization of long His $_{6}$-H5 HA antigen lead to further increase of the peak separation to $287 \mathrm{mV}$ (Fig. S1, curve d) and increase the electron transfer resistance to $14.6 \mathrm{k} \Omega$ (Fig. S2, curve d). The blocking of remaining free space on the electrode surface with BSA leads to an increase of the CV peak separation to $523 \mathrm{mV}$ (Fig. S1, curve e) as well as electron transfer resistance to $55.2 \mathrm{k} \Omega$ (Fig. S2, curve e). 


\subsection{Detection of the Mab 6-9-1 monoclonal antibodies in buffer}

Quantitative assessment of sensitivity of two immunosensors (based on long or short variants of $\mathrm{His}_{6}-\mathrm{H} 5 \mathrm{HA}$ antigen) was performed using a serial dilutions of the anti-H5 HA monoclonal antibody (Mab 6-9-1) in PBS buffer. A typical response of the immunosensor equipped with the long His $_{6}$-H5 HA antigen in PBS measured by EIS is shown in Fig. 1. Electron transfer resistance measured for the immunosensor before antibodies detection in pure PBS buffer $\mathrm{R}_{0}$ (Fig. 1. curve a) was used for calculation of relative response towards a specific analyte. Addition of increasing concentrations of Mab 6-9-1 increases the electron transfer resistance $\mathrm{R}_{\mathrm{i}}$ (Fig. 1, curves b-f).

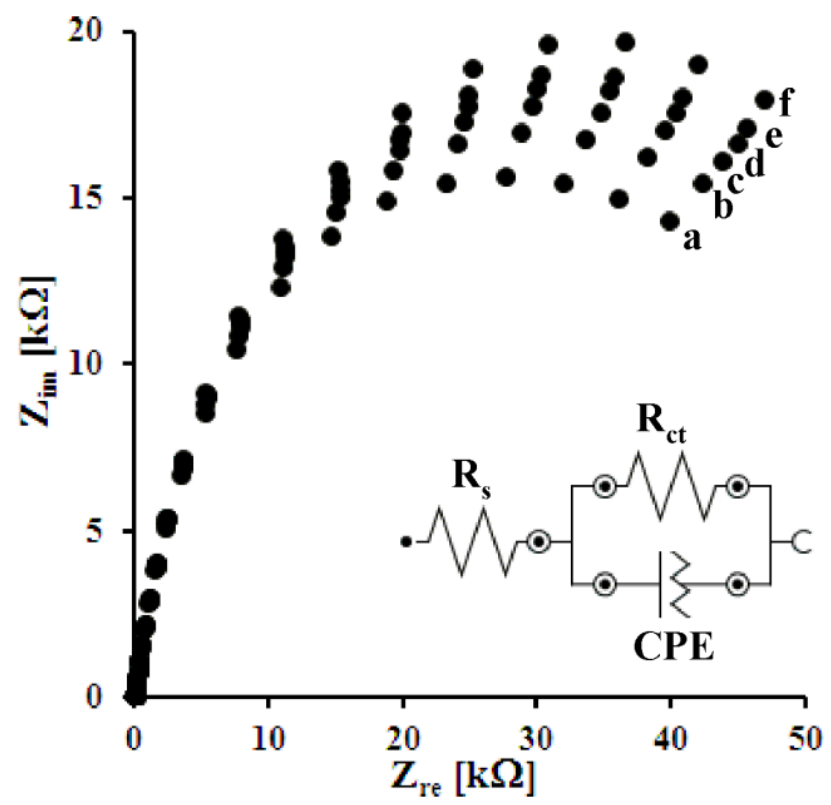

Fig. 1. Electrochemical impedance spectra of BSA / long $\mathrm{His}_{6}-\mathrm{H} 5 \mathrm{HA} /$ anti-His / protein A modified electrode (a) in buffer solution and after treatment with (b) 4; (c) 8, (d) 12; (e) 16; (f) $20 \mathrm{pg} / \mathrm{mL}$ Mab 6- 9-1 in PBS buffer. The measuring conditions: three electrode configurations - GC working electrode, $\mathrm{Ag} / \mathrm{AgCl}$ reference electrode and $\mathrm{Pt}$ counter electrode; a bias potential of $0.2 \mathrm{~V}$; the frequency range from $0.1 \mathrm{~Hz}$ to $10 \mathrm{kHz}$. Circuit model used for fitting Nyquist plots in inset: $\mathrm{R}_{\mathrm{s}}$ - solution resistance, $\mathrm{R}_{\mathrm{et}}$ - electron transfer resistance, CPE-constant phase element.

Both immunosensors incorporated long, as well, as short version of $\mathrm{His}_{6}$-H5 HA antigen were selective and sensitive. The highest concentration of Mab 6-9-1 caused the significant increase of electron transfer resistance, to $23.4 \pm 1.5 \%$ in the case of the long His $_{6}$-H5 HA antigen (Fig. 2) and to $19.1 \pm 0.6 \%$ in the case of the short His ${ }_{6}$-H5 HA antigen (Fig. 3S). In both cases the increase of electron transfer resistance linearly varied with the concentration of Mab 6-9-1. 
The linear range of analytical response from 4 to $20 \mathrm{pg} / \mathrm{mL}$ is probably limited by the number of $\mathrm{His}_{6}-\mathrm{H} 5 \mathrm{HA}$ molecules immobilized on the electrode surface as a sensing element responsible for Mab 6-9-1 detection. The optimal dynamic range with good liner relation was found between the antibody concentration and relative electron transfer resistance $\left(\left[\mathrm{R}_{\mathrm{i}}-\mathrm{R}_{0}\right] / \mathrm{R}_{0}\right)$. This parameter has been proved and reported by $\mathrm{Li}$ et al. (Li et al., 2005a; Li et al.,2005b).

The limits of detection (LOD) and the limits of quantification (LOQ) were calculated using the equations: $\mathrm{LOD}=3.3 \mathrm{\sigma} / \mathrm{S}$ and $\mathrm{LOQ}=10 \mathrm{\sigma} / \mathrm{S}$ (where $\sigma$ is the standard deviation of the response and $\mathrm{S}$ is the slope of the calibration curve) (Swartz and Krull, 2012). In case of the immunosensor based on the long $\mathrm{His}_{6}-\mathrm{H} 5$ HA antigen the LOD and LOQ values obtained were $2.1 \mathrm{pg} / \mathrm{mL}$ and $6.3 \mathrm{pg} / \mathrm{mL}$, respectively. In case of the immunosensor based on the short $\mathrm{His}_{6}$-H5 HA antigen LOD and LOQ were found to be $2.6 \mathrm{pg} / \mathrm{mL}$ and $8 \mathrm{pg} / \mathrm{mL}$, respectively. Rather close values for both antigens suggest that monoclonal Mab 6-9-1 is probably directed towards epitope present in the H1 subunit of HA protein.

The monoclonal mouse antibodies against chicken IL2 were used to control the interaction between antigen (H5 HA) and the specific antibodies recognizing $\mathrm{H} 5 \mathrm{HA}$ (Mab 6- 9-1). The lack of affinity of the anti-IL-2 to H5 HA was confirmed by ELISA (results not shown).

The control anti-IL-2 antibody generated negligible responses. At the presence of antiIL-2 highest concentration $(20 \mathrm{pg} / \mathrm{mL})$ only $5.7 \pm 1.1 \%$ and $6.9 \pm 0.9 \%$ of electron transfer resistance increase were recorded for electrode incorporated long $\mathrm{His}_{6}$-H5 HA antigen (Fig.2) and short His $_{6}$-H5 HA antigen (Fig. S3), respectively. 


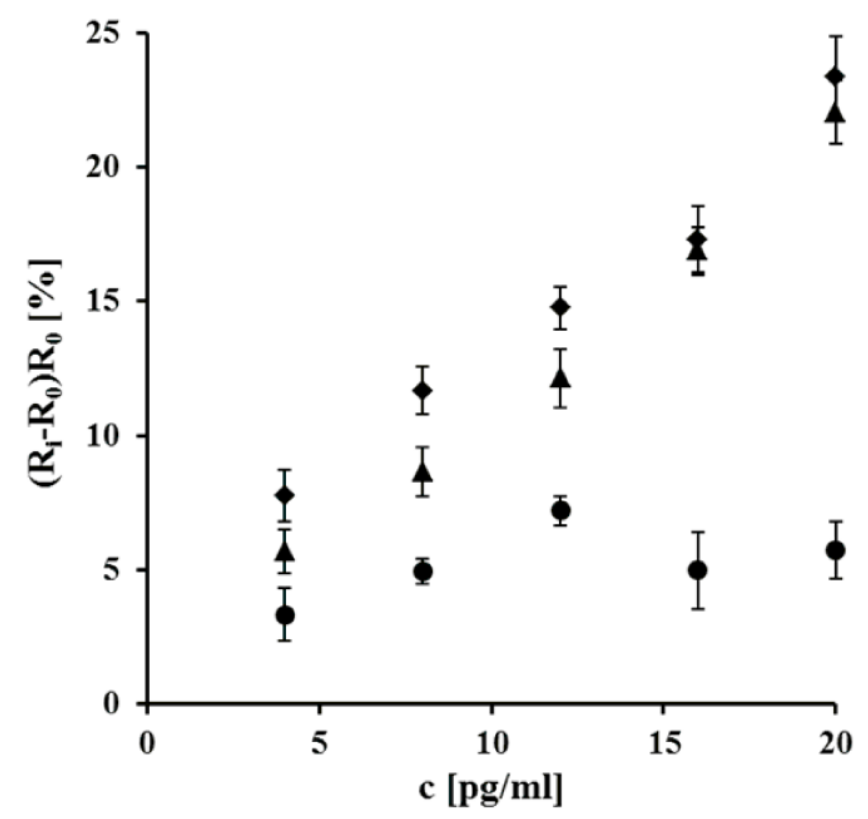

Fig. 2. The relationship of $\left(\mathrm{R}_{\mathrm{i}}-\mathrm{R}_{0}\right) / \mathrm{R}_{0}$ vs. c $[\mathrm{pg} / \mathrm{mL}]$ of $(\bullet)$ Mab 6-9-1, ( $\left.\mathbf{\Delta}\right)$ Mab 6-9-1 in the presence of a constant concentration of anti-IL-2 antibody $(12 \mathrm{pg} / \mathrm{mL}),(\bullet)$ anti-IL-2 antibody. EIS measurements were done with the immunosensor based on the long variant of $\mathrm{His}_{6}-\mathrm{H} 5 \mathrm{HA}$ antigen $(n=4) . R_{0}$ - electron transfer resistance of fully modified electrode measured in pure PBS buffer before antibodies detection, $\mathrm{R}_{\mathrm{i}}$ - electron transfer resistance of fully modified electrode measured in PBS buffer containing particular concentration of antibodies.

In order to check the potential cross reactivity with other antibody the impedimetric measurements were performed for a series of dilutions of Mab 6-9-1 in PBS buffer in the presence of a constant concentration of anti-IL-2 antibody (Fig. 2). The presence of $12 \mathrm{pg} / \mathrm{mL}$ of anti-IL-2 antibody only slightly reduced the impedimetric response of the immunosensor towards Mab 6-9-1. Highest concentration of Mab 6-9-1 in the presence of $12 \mathrm{pg} / \mathrm{mL}$ of antiIL-2 antibody generates responses $22.1 \pm 1.2 \%$. The LOD and LOQ values obtained were $2.9 \mathrm{pg} / \mathrm{mL}$ and $8.6 \mathrm{pg} / \mathrm{mL}$, respectively. The slopes of calibration curves for Mab 6-9-1 and for Mab 6-9-1 in the presence of anti-IL-2 were very similar (Fig. 2). At the same time, when only anti-IL-2 was present in the buffer solution, immunosensor response was very small, with the slope ca. 10 times lower in the comparison to Mab 6-9-1 calibration slopes. These data confirmed that the immunosensor incorporated long $\mathrm{His}_{6}$-H5 HA antigen is able to recognize the specific antibody Mab 6-9-1 in the selective way. 


\subsection{Detection of the anti hemagglutinin antibody in hen sera}

The good analytical parameters such as the linear responses towards Mab 6-9-1 monoclonal antibodies present in the buffer solutions, as well as negligible responses of control anti-IL-2 (Fig. 2), suggested that immunosensor could be successfully applied for detection of humoral response in serum. Immunosensor with the long version of $\mathrm{His}_{6}-\mathrm{H} 5 \mathrm{HA}$ antigen was used in these experiments. A series of dilutions of the sera from the vaccinated and not-vaccinated hens were prepared in PBS buffer. The positive and negative sera were selected from the samples of blood collected previously from two groups of chickens, immunized with DNA vaccine based on His $_{6}-\mathrm{H} 5$ HA and the control group immunized with the empty vector, respectively. The decreased dilutions of the vaccinated hen serum resulted in the increase of the electron transfer resistance (Fig. 3). The sensor was able to detect antiHA antibody in serum diluted $7 \times 10^{7}$-fold. The electrochemical impedance spectra recorded for electrode incorporated long version of $\mathrm{His}_{6}-\mathrm{H} 5 \mathrm{HA}$ in the presence of diluted vaccinated and unvaccinated hen sera were presented in Fig.S4, A,B (Supporting Information).

The dilution range from $1: 7 \times 10^{3}$ to $1: 7 \times 10^{7}$ of vaccinated hen serum suitable for specific antibodies detection was found experimentally. In this range we have received the good linear relation between the relative electron transfer resistance $\left(\left[\mathrm{R}_{\mathrm{i}}-\mathrm{R}_{0}\right] / \mathrm{R}_{0}\right)$ (Li et al., 2005a, Li et al. 2005b) and vaccinated hen serum dilution rate (Fig. 3). The immunosensor was able to detect the specific antibodies in the selective way. The slope of relative electron transfer resistance $\left(\left[\mathrm{R}_{\mathrm{i}}-\mathrm{R}_{0}\right] / \mathrm{R}_{0}\right)$ and unvaccinated hen serum dilution rate was ca. 3 times lower in the comparison to slope recorded for vaccinated hen serum dilution rate (Fig. 3). Therefore, the good sensitivity and selectivity of the presented system allowed for safely distinguishing of hens vaccinated against influenza virus from those non-vaccinated. 


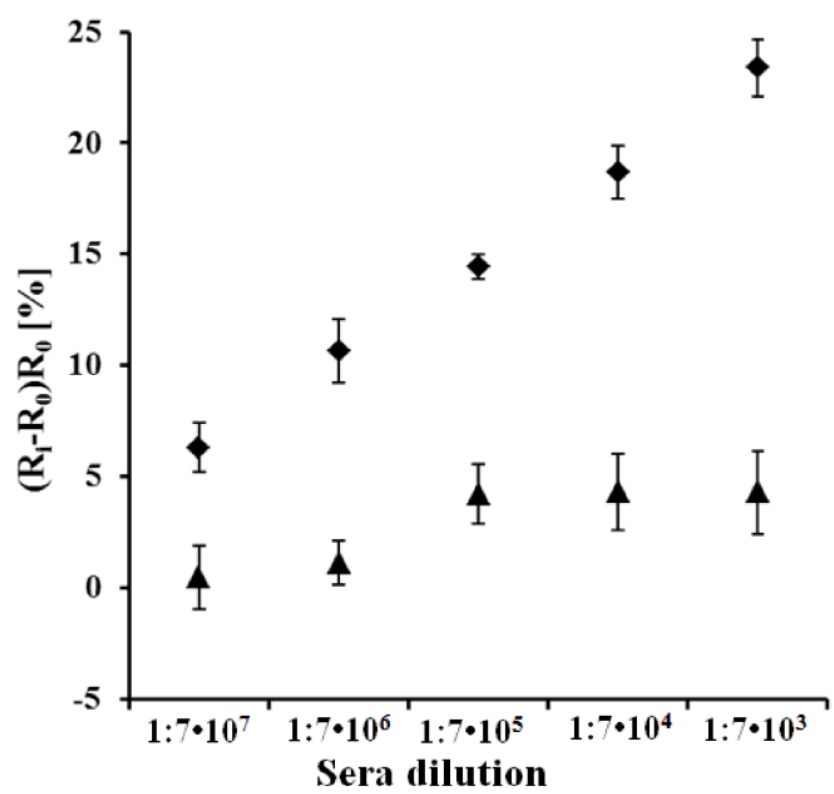

Fig. 3. The relationship of $\left(\mathrm{R}_{\mathrm{i}}-\mathrm{R}_{0}\right) / \mathrm{R}_{0}$ vs. sera dilutions of ( $\bullet$ vaccinated and ( $\left.\boldsymbol{\Delta}\right)$ non-vaccinated hens. EIS measurements were done with the immunosensor based on the long variant of $\mathrm{His}_{6}-\mathrm{H} 5 \mathrm{HA}$ antigen $(n=8)$. $R_{0}$-electron transfer resistance of fully modified electrode measured in the presence of PBS buffer before antibodies detection, $\mathrm{R}_{\mathrm{i}}$ - electron transfer resistance of fully modified electrode measured in the presence of sera form vaccinated or unvaccinated hen diluted with PBS buffer.

Immunosensor containing the short version of $\mathrm{His}_{6}-\mathrm{H} 5 \mathrm{HA}$ antigen was not suitable for detection of antibody response in serum. We noted that immunosensor carrying the short variant, when tested with serum, gave almost negligible signals. The electrochemical signals were very weak with lack of the selectivity (data not shown).

This might suggested that antibodies recognizing the short variant of the $\mathrm{His}_{6}-\mathrm{H} 5 \mathrm{HA}$ antigen represent rather minor components of the polyclonal antibody population present in the sera of hen immunized with the DNA vaccine. In addition, it hints that the proposed sensors, when equipped with different variants of HA antigen (or other antigens) may be useful in analysis of the polyclonal response against subunit vaccines, especially the DNAbased ones, and may be of interest for mapping the epitopes exposed by during such nonstandard presentations of HA antigen.

The results of ELISA test performed with serial dilutions of Mab 6-9-1 from $5.5 \mu \mathrm{g} / \mathrm{mL}$ to $34.8 \mathrm{ng} / \mathrm{mL}$ and of chicken sera (from 1:2000 to 1:64000) are shown in Fig. S5A and Fig. S5 B, respectively (Supporting Information). The lowest concentration of Mab 6-9-1 which was able to detect the long variant of $\mathrm{His}_{6}-\mathrm{H} 5$ HA was limited to $137.5 \mathrm{ng} / \mathrm{mL}$. Moreover, the lowest serum dilution enabling detection of anti-H5 HA 
antibodies was 1:8000. These results indicate that the sensitivity of EIS immunosensor was nearly $10^{4}$ times much better than ELISA.

The immunosensor presented displayed better detection limit in the comparison to those already prepared in our laboratory (Table 1) (Jarocka et al., 2013, 2011). The main reason for this could be the different way of immobilization procedures of sensing elements on the electrode surface. The antibodies suitable for determination of Plum Pox Virus (PPV) were deposited on the colloidal gold nanoparticles layer mainly via electrostatic interactions. Thus, the antibodies orientation on the electrode surface is rather random (Jarocka et al., 2011). For recognitions of Prunus Necrotic Ringspot Virus (PNRV), the antibodies were attached to via protein A. This approach provided more stable and oriented antibodies immobilization (Jarocka et al., 2013). In the work presented, the interactions between anti-His IgG monoclonal antibody deposited on the electrode surface and His-tagged hemagglutinin (His 6 -H5 HA) were applied. This assured stable and oriented sensing element immobilization, which is crucial for sensor sensitivity.

Taking into account the parameters such as sensitivity and selectivity, as well as suitability for analyte determination in real samples, the immunosensor presented is superior to numerous immunosensors already reported (Table 1). It is worth to emphasize that the main advantages of the immunosensor proposed here are its simple fabrication, with the possibility for miniaturization, very small sample volume and the suitability for determination of the antibody directly in diluted hen sera.

Table 1. Comparison of immunosensor presented with those already published.

\begin{tabular}{|c|c|c|c|c|}
\hline Antibody & Sensor type & $\begin{array}{l}\text { Detection } \\
\text { limit }\end{array}$ & $\begin{array}{l}\text { Determination } \\
\text { in real samples }\end{array}$ & References \\
\hline Mab 10B2 & SPR & $5 \mu \mathrm{g} / \mathrm{mL}$ & not determined & $\begin{array}{c}\text { Puttharugsa et al., } \\
2013\end{array}$ \\
\hline anti-cholera & photoelectrochemical & $0.2 \mu \mathrm{g} / \mathrm{mL}$ & not determined & $\begin{array}{c}\text { Wenjuan et al., } \\
2013\end{array}$ \\
\hline $\mathrm{SjAb}$ & amperometric & $50 \mathrm{ng} / \mathrm{mL}$ & $\begin{array}{c}14.3 \mu \mathrm{g} / \mathrm{mL} \text { in } \\
\text { rabbit serum }\end{array}$ & Zhou et al., 2003 \\
\hline $\begin{array}{c}\text { anti-biotin } \\
\text { IgG }\end{array}$ & EIS & $5 \mathrm{ng} / \mathrm{mL}$ & not determined & Liu et al., 2011 \\
\hline $\operatorname{IgE}$ & SPR & $2.07 \mathrm{ng} / \mathrm{mL}$ & not determined & Kim et al., 2009 \\
\hline anti-IgE & DPV & $0.204 \mathrm{ng} / \mathrm{mL}$ & not determined & Anik et al., 2011 \\
\hline anti-EBNA & SPR & $0.2 \mathrm{ng} / \mathrm{mL}$ & $\begin{array}{l}1 \% \text { human } \\
\text { serum }\end{array}$ & $\begin{array}{l}\text { Vaisocherová } \\
\text { et al., } 2007\end{array}$ \\
\hline anti-E & $\mathrm{CV}$ & $91 \mathrm{pg} / \mathrm{mL}$ & $0.2 \mathrm{ng} / \mathrm{mL}$ & Pereira et al., 2011 \\
\hline
\end{tabular}


granulosus

\begin{tabular}{|c|c|c|c|c|}
\hline $\operatorname{IgY}$ & $\begin{array}{c}\text { nonfaradaic } \\
\text { impedance }\end{array}$ & $\begin{array}{c}\text { not } \\
\text { determined }\end{array}$ & $\begin{array}{c}5 \mathrm{pg} / \mathrm{mL} \text { in calf } \\
\text { serum }\end{array}$ & Liu et al., 2010 \\
\hline PPV & EIS & $10 \mathrm{pg} / \mathrm{mL}$ & $\begin{array}{c}\text { 1:106 diluted } \\
\text { plum leaf } \\
\text { extract }\end{array}$ & $\begin{array}{c}\text { Jarocka et al., } \\
2011\end{array}$ \\
\hline PNRSV & EIS & $\begin{array}{c}\text { not } \\
\text { determined }\end{array}$ & $\begin{array}{l}\text { 1:106 diluted } \\
\text { cucumber leaf } \\
\text { extract }\end{array}$ & $\begin{array}{c}\text { Jarocka et al., } \\
2013\end{array}$ \\
\hline Iab 6-9-1 & EIS & $2.1 \mathrm{pg} / \mathrm{mL}$ & $\begin{array}{l}\text { 1:7x } 107 \text { diluted } \\
\text { vaccinated hen } \\
\text { serum }\end{array}$ & This work \\
\hline
\end{tabular}

Abbreviations Mab 10B2: monoclonal antibody 10B2 against bacterium Acidovorax avenae subsp. citrulli, SjAb: antibody against Schistosoma japonicum, IgE: human immunoglobulin, anti-EBNA: antibodies against the Epstein-Barr virus, anti-E granulosus: antibodies against Echinococcus granulosus, IgY: antipeanut antibody, DPV: differential pulse voltammograms, PPV: Plum Pox Virus, PNRSV: Prunus Necrotic Ringspot Virus.

\section{Conclusions}

The electrochemical immunosensor presented is based on a glassy carbon electrode modified subsequently with: protein A, anti-His monoclonal antibody, recombinant $\mathrm{His}_{6}$-H5 $\mathrm{HA}$ antigen and BSA. It was used for determination of the presence anti-hemagglutinin $\mathrm{H} 5$ monoclonal antibody in buffer and verified for detection of anti-H5 HA antibodies in chicken sera. The proposed electrochemical impedance spectroscopy (EIS) immunosensor displayed a very low detection limit equal to $2.1 \mathrm{pg} / \mathrm{mL}$ and the limit quantification of $6.3 \mathrm{pg} / \mathrm{mL}$. The monoclonal anti-IL-2 antibody, used as a negative (unspecific to the target - His $_{6}$-H5 HA) control, generated weak responses. The sensor was able to detect humoral response in serum of hen immunized with DNA vaccine based on the sequence of HA from the H5N1 in all tested serum dilutions (10-fold serial dilutions in the range from $7 \times 10^{3}$ to $7 \times 10^{7}$ ). Sensitivity of EIS immunosensor was almost $10^{4}$ times much better than ELISA. The presented system is able to safely distinguish between sera of non-vaccinated and vaccinated chickens against the avian influenza virus. Similar sensors, for example equipped with a variant of AIV antigen absent in the applied vaccine, could be also used to differentiate vaccinated individuals from the infected ones. Therefore, it could be very effective 
in detection of antibodies for immune surveillance and monitoring the efficiency of poultry of vaccination programs.

\section{Acknowledgement}

We are grateful to Drs. Anna Porębska, Violetta Sączyńska and Violetta CecudaAdamczewska for hybridoma samples. This work was supported by Innovative Economy Program, No. WND-POIG.01.01.02-00-007/08 and Institute of Animal Reproduction and Food Research of Polish Academy of Sciences, Olsztyn, Poland.

\section{References}

Allwinn, R., Geiler, J., Berger, A., Cinatl, J., Doerr, H.W., 2010. Med. Microbiol. Immunol. 199, 117-121.

Anik, Ü., Cevik, S., Timur, S., 2011. Electroanalysis 23, 2379-2385.

Boon, A.C.M., French, A.M.F., Fleming, D.M., Zambon, M.C., 2001. J. Med. Virol. 65, 163170 .

Boujday, S., Bantegnie, A., Briand, E., Marnet, P.-G., Salmain, M., Pradier, C.-M., 2008. J. Phys. Chem. B 112, 6708-6715.

Caygill, R.L., Hodges, C.S., Holmes, J.L., Higson, S.P.J., Blair, G.E., Millner P.A., 2012. Biosens. Bioelectron. 32, 104-110.

Chen, Y., Luo, W., Song, H., Yin, B., Tang, J., Chen, Y., Ng, M.H., Yeo, A.E.T., Zhang, J., Xia, N., 2011. PLoS One 6, e24144.

Ciacci-Zanella, J.R., Vincent, A.L., Prickett, J.R., Zimmerman, S.M., Zimmerman, J.J., 2010. J. Vet. Diagn. Invest. 22, 3-9.

Dhumpa, R., Handberg, K.J., Jørgensen, P.H., Yi, S., Wolff, A., Bang, D.D., 2011. Diagn. Microbiol. Infect. Dis. 69, 258-265.

Guan, Y., Peiris, J.S.M., Lipatov, A.S., Ellis, T.M., Dyrting, K.C., Krauss, S., Zhang, L.J., Webster, R.G., Shortridge, K.F., 2002. PNAS 99, 8950-8955.

Gupta, G., Sharma, P.K., Sikarwar, B., Merwyn, S., Kaushik, S., Boopathi, M., Agarwal, G.S., Singh, B., 2012. Biosens. Bioelectron. 36, 95-102. 
Hoque, M. A., Skerratt, L. F., Garland, S., Burgess, G. W., Selleck, P., 2012. Indian J. Virol. $23,261-269$.

Ionescu, R.E., Cosnier, S., Herrmann, S., Marks, R.S., 2007. Anal. Chem. 79, 8662-8668.

Kim, Y.H., Kim, J.P., Han, S.J., Sim, S.J., 2009. Sens. Actuat. B 139, 471-475.

Lebarbenchon, C., Brown, J.D., Luttrell, M.P., Stallknecht, D.E., 2012. J. Vet. Diagn. Invest. 24, 161-165.

Jarocka, U., Wąsowicz, M., Radecka, H. Malinowski, T., Michalczuk, L., Radecki, J., 2011. Electroanalysis 23, 2197-22204.

Jarocka, U., Radecka, H. Malinowski, T., Michalczuk, L., Radecki, J., 2013. Electroanalysis $25,433-438$.

Lee, H.J., Namkoong, K., Cho, E.C., Ko, C., Park, J.C., Lee, S.S., 2009. Biosens. Bioelectron. 24, 3120-3125.

Li, D., Wang, J., Wang, R., Li, Y., Abi-Ghanem, D., Berghman, L., Hargis, B., Lu, H., 2011. Biosens. Bioelectron. 26, 4146-4154.

Liu, G., Liu, J., Davis, T.P., Gooding, J.J., 2011. Biosens. Bioelectron. 26, 3660-3665.

Liu, H., Malhotra, R., Peczuh, M.W., Rusling, J.F., 2010. Anal. Chem. 82, 5865-5871.

Lum, J., Wang, R., Lassiter, K., Srinivasan, B., Abi-Ghanem, D., Berghman, L., Hargis, B., Tung, S., Lu, H., Li, Y., 2012. Biosens. Bioelectron.38, 67-73.

Li, C.M., Sun, C.Q., Song, S., Choong, V.E., Maracas, G., Zhang, X.J., 2005a. Front. Biosci. 10, 180-186.

Li, C.M., Chen W., Yang, X., Sun, C.Q., Gao, C., Zheng, Z.X., Sawyer, J., 2005b. Front. Biosci. 10, 2518-2526.

Lvovich, V.F., Impedance spectroscopy aplications to Electrochemical and Dielectric Phenomena, WILEY A John Wiley \& Sons, INC., Hoboken, New Jersey 2012.

Mashazi, P., Tetyana, P., Vilakazi, S., Nyokong, T., 2013. Biosens. Bioelectron. 49, 32-38.

Moreno, A., Lelli, D., Brocchi, E., Sozzi, E., Vinco, L.J., Grilli, G., Cordioli, P., 2013. J. Virol. Meth. 187, 424-430.

Nilsson, C.E., Abbas, S., Bennemo, M., Larsson, A., Hämäläinen, M.D., Frostell-Karlsson, Å., 2010. Vaccine 28, 759-766.

Pang, D.-W., Zhang, M., Wang, Z.-L., Qi, Y.-P., Cheng, J.-K., Liu, Z.-Y., 1996. J. Electroanal. Chem. 403, 183-188.

Peng, D.P., Hu, S.S., Hua, Y., Xiao, Y.C., Li, Z.L., Wang, X.L., Bi, D.R., 2007. Vet. Immunol. Immunopathol. 117, 17-25.

Pereira, S.V., Bertolino, F.A., Messina, G.A., Raba, J., 2011. Anal. Biochem. 409, 98-104. 
Puttharugsa, C., Wangkam, T., Houngkamhang, N., Yodmongkol, S., Gajanandana, O., Himananto, O., Sutapun, B., Amarit, R., Somboonkaew, A., Srikhirin, T., 2013. Curr. Appl. Phys. 13, 1008-1013.

Ricci, F., Adornetto, G., Palleschi,G., 2012. Electrochem. Acta 84, 74-83.

Schultsz, C., Dung, N.V., Hai, L. T., Ha, D.Q., Peiris, J.S.M., Lim, W., Garcia, J.-M., Tho, N.D., Lan, N.T.H., Tho, H.H., Thao, P.X., Doorn, H.R., Chau, N.V., Farrar, J., Jong, M.D., 2009. PLoS One 4, e7948.

Shen, G., Wang, H., Tan, S., Li, J., Shen, G., Yu, R., 2005. Anal. Chim. Acta 540, 279-284.

Shortridge, K.F., Zhou, N.N., Guan, Y., Gao, P., Ito, T., Kawaoka, Y., Kodihalli, S., Krauss, S., Markwell, D., Murti, K.G., Norwood, M., Senne, D., Sims, L., Takada, A., Webster, R.G., 1998. Virology 252, 331-342.

Souto, D.E.P., Silva, J.V., Martins, H.R., Reis, A.B., Luz, R.C.S., Kubota L.T., Damos, F.S., 2013. Biosens. Bioelectron. 46, 22-29.

Swartz, M. E., Krull, I.S., Handbook of analytical validation, CRC Press, Taylor \& Francis Group, Boca Raton 2012, pp.70-71.

Uyeki, T.M., Nguyen, D.C., Rowe, T., Lu X., Hu-Primmer, J., Huynh, L.P., Hang, N.L.K., Katz, J.M., 2012. PLoS One 7, e43948.

Vaisocherová, H., Mrkvová, K., Piliarik, M., Jinoch, P., Šteinbachová, M., Homola, J., 2007. Biosens. Bioelectron. 22, 1020-1026.

Wang, S., Yin, T., Zeng, S., Che, H., Yang, F., Chen, X., Shen, G., Wu, Z., 2012. PLoS One 7, e30779.

Wąsowicz, M., Viswanathan, S., Dvornyk, A, Grzelak, K., Kłudkiewicz, B., Radecka, H., 2008. Biosens. Bioelectron. 24, 284-289.

Wąsowicz, M., Milner, M., Radecka, D., Grzelak, K., Radecka, H., 2010. Sensors 10, 54095424.

Wenjuan, Y., Goff, A.L., Spinelli, N., Holzinger, M., Diao, G.-W., Shan, D., Defrancq, E., Cosnier, S., 2013. Biosens. Bioelectron. 42, 556-562.

Zhou, Y.-M., Wu, Z.-Y., Shen, G.-L., Yu, R-Q., 2003. Sens. Actuat. B 89, 292-298.

Yuanyuan, X., Shanhong, X., Chao, B., Shaofeng, C., 2006. Sci. China F 49, 397-408. 